\title{
Potensi dan Permasalahan Usaha Perikanan di Kecamatan Cantigi Kabupaten Indramayu
}

\author{
[Potential and Problem of Fisheries Business \\ In Cantigi District Indramayu District]
}

\section{Arrofi Nur Risyandi, lin Siti Djunaidah, M. Harja Supena}

Jurusan Penyuluhan Perikanan Sekolah Tinggi Perikanan

Jl. Cikaret No. 2 Bogor Selatan Kota Bogor

\begin{abstract}
Abstrak
Kecamatan Cantigi merupakan salah satu wilayah adminitrasi di Kabupaten Indramayu yang memiliki potensi geografis dan sumberdaya yang baik untuk produksi usaha perikanan. Kecamatan Cantigi memiliki potensi perikanan budidaya air payau yang merata dari masing komoditas dan memiliki potensi terbesar dalam komoditas rumput laut, bandeng dan udang windu (DKP Indramayu, 2015). Penelitian ini bertujuan untuk mengidentifikasi potensi dan permasalahan perikanan di Kecamatan Cantigi, meliputi penggalian data potensi sumberdaya alam, sumberdaya manusia, sehingga dapat diperoleh data aktual dan potensialnya yang kemudian di analisis untuk mengetahui masalah yang dihadapi dalam suatu wilayah. Penelitian ini dilaksanakan pada bulan November 2018 dengan menggunakan metode survei. Penentuan responden dilakukan bedasarkan Purposive Sampling dan penetapan responden menggunakan rumus Slovin dengan galat (e) $20 \%$, Analisis data deskriptif yang digunakan dalam penelitian ini menggunakan Pohon Masalah (Fault Tree Analysis) untuk menentukan sebab - akibat permasalahan yang ada (Anthony, 2015). Hasil penelitian menunjukkan besarnya potensi perikanan yang ada di Kecamatan Cantigi, namun dalam segi pemanfaatan dalam produksi di masing-masing sektor bidang perikanan masih kurang, didasarkan pada permasalahan teknis, sosial dan ekonomi yang ada di Kecamatan Cantigi. Permasalahan yang terdapat di Kecamatan Cantigi yang umum terjadi di masyarakat dalam bidang teknis ; a) nelayan yang masih belum menerapkan rantai dingin, b) pembudidaya belum melaksanakan pengelolaan pakan yang sesuai dan c) pengolah yang belum menerapkan sanitasi higiens pada proses produksi. Analisis GMP pada aspek sosial ; a) Kesadaran anggota kelompok dalam partisipasi kegiatan kelompoknya masih rendah, pada aspek ekonomi; a) harga bahan produksi yang tinggi.
\end{abstract}

Kata Kunci : Potensi dan Permasalahan, Kecamatan Cantigi, Usaha Perikanan.

\section{Abstract}

Cantigi District is one of the administrative areas in Indramayu Regency that has good geographical potential and resources for fisheries production. Cantigi District has the potential of brackish water aquaculture that is evenly distributed from each commodity and has the greatest potential in commodity seaweed, milkfish and tiger shrimp (DKP Indramayu, 2015). This study aims to identify the potential and problems of fisheries in Cantigi Subdistrict, including extracting data on potential natural resources, human resources, so that actual and potential data can be obtained which are then analyzed to find out the problems faced in a region. This research was conducted in November 2018 using the survey method. Determination of respondents is based on Purposive Sampling and determination of respondents using Slovin formula with error (e) $20 \%$, Analysis of descriptive data used in this study using the Problem Tree (Fault Tree Analysis) to determine the causes - problems that exist (Anthony, 2015). The results showed the magnitude of the potential of fisheries in Cantigi Subdistrict, but in terms of utilization in production in each sector of fisheries is still lacking, based on technical, social and economic problems in Cantigi District. The problems found in Cantigi District are common in the community in the technical field; a) fishermen who still have not applied the cold chain, b) farmers have not implemented 
appropriate feed management and c) processors that have not implemented sanitation hygiene in the production process. GMP analysis on social aspects; a) Awareness of group members in group activity participation is still low, on economic aspects; a) high production material prices.

Keywords: Potential and Problems, Cantigi District, Fisheries Business

Penulis Korespondensi

Arrofi Nur Risyandi | risyandi.arrofi@gmail.com

\section{PENDAHULUAN}

Kabupaten Indramayu menjadi salah satu kabupaten penghasil ikan terbesar di Jawa Barat. Berada di pesisir pantai, Kabupaten Indramayu memproduksi ikan laut segar sebanyak 139.713,39 ton pada tahun 2017. Nilai produksinya mengalami peningkatan dari Rp.2.375.299.996,36,- pada tahun 2016, menjadi Rp. 2.413.781.346,31,- pada tahun 2017 (BPS 2017). Kecamatan Cantigi merupakan salah satu wilayah adminitrasi pemerintahan di Kabupaten Indramayu yang memiliki produksi perikanan tertinggi dari kecamatan lainnya dengan total produksi 26.973,63 ton ikan segar (BPS 2012). Bedasarkan data potensi wilayah tersebut, Kecamatan Cantigi memiliki potensi perikanan budidaya Air Payau yang merata dari masing komoditas dan memiliki potensi terbesar dalam komoditas rumput laut, bandeng dan udang windu (BPS 2015).

Namun potensi geografis, sumberdaya, serta produksi yang meningkat setiap tahun di Kecamatan Cantigi tidak disertai pertumbuhan yang baik dan stabil, hal tersebut dapat menyebabkan masalah sosial, ekonomi dan teknis. Maka perencanaan dan pengembangan usaha perikanan perlu dilakukan untuk mengoptimalkan potensi perikanan yang ada di Kecamatan Cantigi, Kabupaten Indramayu.

Berkaitan dengan hal tersebut, penelitian ini bertujuan untuk megidentifikasi potensi dan permasalahan di wilayah Kecamatan Cantigi yang berkaitan dengan perikanan, meliputi penggalian data potensi sumberdaya alam, sumberdaya manusia. Data aktual maupun data potensial kemudian di analisis untuk mengetahui masalah yang dihadapi dalam suatu wilayah, sehingga masalah tersebut dapat disusun dan dibahas dalam Rencana Kerja Penyuluhan di Kecamatan Cantigi.

\section{BAHAN DAN METODE}

\section{Waktu dan Lokasi Penelitian}

Kegiatan Penelitian dilaksanakan pada tanggal 1 November 2018 s/d 30 November 2018 yang bertempat di Kecamatan Cantigi. Penelitian ini 
difokuskan pada desa yang memiliki potensi perikanan berdasarkan kriteria serta pertimbangan di Kecamatan Cantigi Kabupaten Indramayu Provinsi Jawa Barat.

\section{Jenis dan Sumber Data}

Bedasarkan hasil penelitian, jenis data yang digunakan terdiri dari data primer dan data sekunder. Adapun yang termasuk dalam data primer dan data sekunder; (a). Data Primer adalah data yang diperoleh langsung dari obyek yang diteliti (Sunyoto 2011), yaitu data produksi (sistem produksi budidaya, produksi pengolahan hasil perikanan dan produksi penangkapan ikan), serta datadata ekonomi pelaku utama perikanan. (b). Data sekunder adalah data yang diperoleh tidak secara langsung dari obyek yang diteliti (Sunyoto 2011). Adapun data yang didapatkan dan termasuk data sekunder yaitu data kondisi umum wilayah (topografi dan monografi wilayah), serta data kondisi umum sumberdaya alam (luas lahan potensial dan data perairan umum), sumberdaya manusia (jumlah rumah tangga perikanan dan data kelompok perikanan) yang ada di Kecamatan Cantigi Kabupaten Indramayu.

Sumber data didapat dari obyek langsung pelaku utama perikanan meliputi pembudidaya, pengolah dan nelayan yang ada di kecamatan Cantigi, penyuluh perikanan dan intansi terkait (Desa/kelurahan, Kecamatan, UPTD Perikanan, Dinas Perikanan dan Kelautan) serta data yang didapat dari literatur, dan hasil laporan (Badan Pusat Statistik Kecamatan Cantigi).

\section{Metode Pengumpulan Data}

Teknik pengumpulan data yang dilakukan yaitu dengan metode observasi dan wawancara yang dilakukan dengan menggunakan alat kuisioner yang ditujukan ke pelaku utama pembudidaya, pengolah dan penangkapan, dengan menggunakan pendekatan metode Participatory Rural Appraisal (PRA) yaitu melakukan pengumpulan data secara langsung di rumah pelaku utama perikanan dengan estimasi waktu \pm 2 jam di setiap rumah tangga perikanan (RTP).

Pengambilan sampel dilakukan dengan menggunakan Purposive sampling dengan kriteria akses lokasi, responden, dan potensial dalam usaha perikanan di Kecamatan Cantigi, sehingga didapat populasi di Kecamatan Cantigi sebanyak 4.432 orang. Ukuran sampel untuk menentapkan responden menggunakan rumus Slovin dengan dengan galat (e) $20 \%$ (Sevilla et al. 1992) sebanyak 26 Orang. 


\section{Penetapan Responden}

Dalam hal ini dapat disimpulkan dari hasil penentuan ukuran sampel didapat orang responden dari 4 desa (Desa Cangring, Cemara, Cantigi Kulon, Cantigi Wetan) potensi bedasarkan Purposive sampling. Penetapan Responden dilakukan untuk mempermudah penentuan jumlah responden di masing - masing desa sampel. Berikut penentuan responden bedasarkan komoditas :

1. Penentuan Sampel Produksi Perikanan Tangkap

$$
\begin{aligned}
& \mathrm{n}(\text { nelayan })=\left(\frac{2.104}{4.432}\right) \times 26 \\
& \mathrm{n}(\text { nelayan })=12 \mathrm{RTP}
\end{aligned}
$$

2. Penentuan Sampel Produksi Budidaya Perikanan

$\mathrm{n}($ pembudidaya $)=\left(\frac{2.233}{4.432}\right) \times 26$

$\mathrm{n}($ pembudidaya $)=13 \mathrm{RTP}$

3. Penentuan Sampel Produksi Pengolahan Hasil Perikanan

$\mathrm{n}($ nelayan $)=\left(\frac{96}{4.432}\right) \times 26$

$\mathrm{n}$ (nelayan) $=1 \mathrm{RTP}$

Dalam penentuan sampel responden pada pengolahan dibutuhkan responden tambahan sehingga menjadi 4 responden Pengolahan Hasil Perikanan di Kecamatan Cantigi.

\section{Analisis Data}

Analisis data deskriptif yang digunakan dalam penelitian ini menggunakan Pohon Masalah (Fault Tree Analysis) untuk menentukan sebab
- akibat permasalahan yang ada (Anthony dan Noya 2015). Fault Tree Anlysis secara umum adalah teknik yang digunakan untuk mengidentifikasi resiko yang mempengaruhi terjadinya kegagalan. Metode ini dilakukan dengan pendekatan terhadap kondisi yang tidak dikehendaki, yang diawali dengan asumsi kegagalan atau kerugian dari kejadian, kemudian merinci sebab akibat suatu Top Event sampai pada kegagalan dasar (Masalah Khusus).

\section{HASIL DAN PEMBAHASAN}

\section{Gambaran Umum Lokasi Penelitian}

Kecamatan Cantigi merupakan wilayah adminitrasi pemerintahan Kabupaten Indramayu yang terletak antara 6 $6^{\circ} 31^{\prime}-6^{\circ} 41^{\prime}$ lintang utara dan antara $108^{\circ} 32^{\prime}$ bujur timur. Bedasarkan topografinya sebagian besar kecamatan Cantigi merupakan dataran atau daerah landai dengan ketinggian antara 0,5-6,13 meter diatas permukaan laut. Desa Cantigi Wetan adalah desa tertinggi dari permukaan laut $6,13 \mathrm{~m} \mathrm{dpl}$ (di atas permukaan laut), dan desa Cangring terendah 0,5 m dpl. (BPS 2018). 


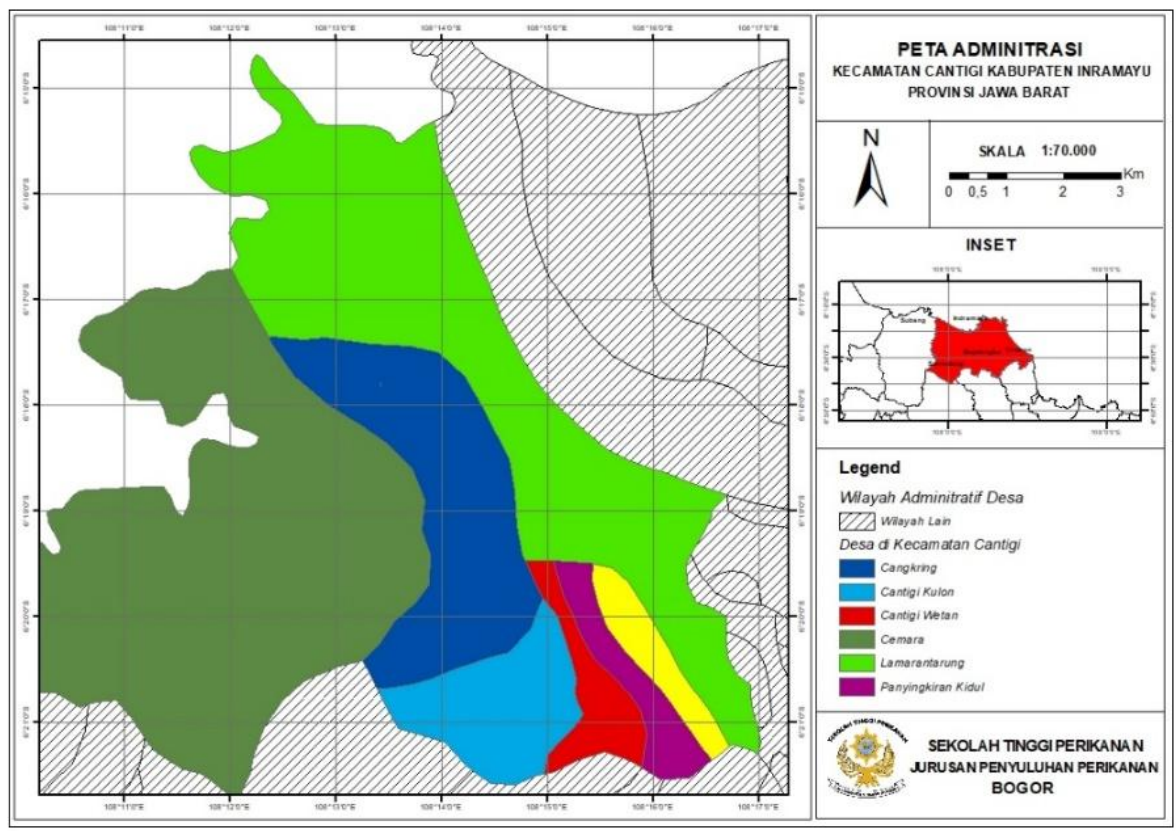

Gambar 1. Peta Wilayah Adminitrasi Kecamatan Cantigi

Kecamatan Cantigi memiliki luas wilayah $\pm 116,84 \mathrm{~km}^{2}$ dengan 7 desa adminitratif (Gambar 1). Intensitas curah hujan di Kecamatan Cantigi pada tahun 2017 yaitu sebesar 120,17 mm dengan jumlah hari hujan 9 hari. Adapun curah hujan tertinggi terjadi di bulan Februari, yaitu $296 \mathrm{~mm}$ dengan 21 hari hujan, curah hujan terendah terjadi di bulan Juli yakni $0 \mathrm{~mm}$ dengan 0 hari hujan (BPS 2017). Kecamatan Cantigi sebagai wilayah yang berpotensi perikanan tentunya memiliki beberapa saluran perairan yang digunakan sebagai sumber utama kegiatan budidaya, nelayan dan juga kegiatan aktifitas masyarakat lainnya, adapun jumlah saluran tersebut berjumlah 27 saluran irigasi dan 2 situ (galian) dari penambangan minyak bumi.
Kondisi Sumberdaya Manusia di Kecamatan Cantigi yang tercatat bedasarkan registrasi penduduk yaitu 27.811 jiwa, dengan jumlah penduduk laki-laki 13.824 dan perempuan 13.987 jiwa. Bedasarkan jenjang usia produktif Kecamatan Cantigi memiliki 19.366 jiwa atau $70 \%$ dari total jumlah penduduk yang berada pada usia produktif dengan rata-rata umur 15-64 tahun. Menurut Badan Pusat Statistik (BPS) kelompok penduduk umur 0-14 tahun dianggap sebagai kelompok penduduk yang belum produktif secara ekonomis, kelompok penduduk umur 15-64 tahun sebagai kelompok penduduk yang produktif, dan kelompok penduduk umur 64 tahun ke atas sebagai kelompok yang tidak lagi produktif. 
Tabel 1. RTP Usaha Perikanan

\begin{tabular}{llccc}
\hline \multirow{2}{*}{ No } & \multicolumn{1}{c}{ Desa } & \multicolumn{2}{c}{ Jumlah Rumah Tangga Perikanan } \\
\cline { 3 - 5 } & & Tangkap & Budidaya & Pengolahan \\
\hline 1 & Cantigi Kulon & $799(35 \%)$ & $223(7 \%)$ & $40(42 \%)$ \\
2 & Cantigi Wetan & - & $167(5 \%)$ & - \\
3 & Cangkring & $378(17 \%)$ & $584(17 \%)$ & $30(32 \%)$ \\
4 & Cemara & $927(41 \%)$ & $1.259(33 \%)$ & $25(26 \%)$ \\
5 & Lamaran Tarung & - & $1.028(27 \%)$ & - \\
6 & Panyingkiran Lor & $168(7 \%)$ & $243(6 \%)$ & - \\
7 & Panyingkiran Kidul & - & $225(6 \%)$ & - \\
\hline & $\quad$ Jumlah & $\mathbf{2 . 2 7 2 ( 3 9 \% )}$ & $\mathbf{3 . 8 1 0 ( 5 9 \% )}$ & $\mathbf{9 5}(\mathbf{2} \%)$ \\
\hline
\end{tabular}

Sumber : Data Hasil Olahan, 2018

\section{Keragaan Usaha Perikanan}

Usaha Perikanan di Kecamatan Cantigi terdiri atas usaha perikanan budidaya, penangkapan ikan dan pengolahan hasil perikanan dengan jumlah total Rumah Tangga Perikanan (RTP) yaitu berjumlah 6.177 RTP (Tabel 1).

Pembudidaya di Kecamatan Cantigi berjumlah 3.810 RTP, perikanan tangkap berjumlah 2.272 RTP, dan Pengolahan 95 RTP. Jumlah RTP terbesar dan tersebar di masing-masing desa yaitu pada usaha perikanan budidaya, adapun jumlah RTP Budidaya tertinggi pada desa Cemara dengan jumlah 1.259 RTP, setelah itu Desa Lamaran Tarung 1.028 RTP, dan RTP Budidaya terendah terdapat pada Desa Cantigi Wetan dengan total 167 RTP.

Perikanan Tangkap yang ada di Kecamatan Cantigi tersebar pada beberapa desa yang memiliki potensi perairan yang luas hulu - hilir kapal nelayan, oleh karena itu hanya terdapat pada desa Cantigi Kulon, Cangkring, Cemara, dan Panyingkiran Lor. Jumlah RTP Perikanan Tangkap yang terbesar yaitu terdapat pada Desa Cemara dan Desa Cantigi Kulon. Hal ini dikarenakan kedua wilayah tersebut berada pada sungai yang lebar serta akses untuk melakukan penangkapan lebih mudah. Alat tangkap ikan yang digunakan nelayan di Kecamatan Cantigi sangat bervariasi dari setiap desa di Kecamatan Cantigi (Tabel 2). Terdapat alat tangkap yang menjadi alat tangkap unggulan yaitu jaring sero dengan jumlah alat 1.010 dan bagan berjumlah 630 . 
Tabel 2. Jenis Penggunaan Alat Tangkap di Kecamatan Cantigi

\begin{tabular}{lcccccc}
\hline \multirow{2}{*}{$\begin{array}{c}\text { Alat } \\
\text { Tangkap }\end{array}$} & \multicolumn{7}{c}{ Desa } & Jumlah \\
\cline { 2 - 6 } & Cangring & $\begin{array}{c}\text { Cantigi } \\
\text { Kulon }\end{array}$ & $\begin{array}{c}\text { Lamaran } \\
\text { Tarung }\end{array}$ & $\begin{array}{c}\text { Panyingkiran } \\
\text { Lor }\end{array}$ & Cemara & \\
\hline Udang & 24 & 5 & 52 & 11 & 347 & 439 \\
Arad & 1 & 79 & - & - & - & 80 \\
Rampus & 4 & 45 & - & - & - & 49 \\
Sero & 7 & 843 & - & - & 160 & 1010 \\
Milenium & 3 & 1 & - & - & 10 & 14 \\
Rajungan & 21 & - & 15 & - & - & 36 \\
Apolio & 7 & - & - & - & - & 7 \\
Kakap & 5 & 7 & - & - & 5 & 17 \\
Pancing & - & - & 160 & - & - & 160 \\
Blanak & 119 & - & - & 10 & 168 & 297 \\
Gillnet & - & 3 & - & - & - & 3 \\
Bagan & - & 250 & - & - & 380 & 630 \\
\hline Jumlah & 191 & 1234 & 227 & 21 & 1070 & 2743 \\
\hline
\end{tabular}

Sumber. Data Rencana Kerja UTPD Kecamatan Cantigi Tahun, 2018

Ambari (2017) menjelaskan bahwa jumlah kapal penangkapan ikan kecil mendominasi dari total kapal penangkapan ikan di Indonesia. Kapal penghasil ikan didominasi oleh kapal penangkapan ikan kecil yang hanya mampu melakukan aktifitas penangkapan di sekitar perairan pantai, sekitar 12 mil dari bibir pantai. Demikian pula yang terjadi di Kecamatan Cantigi para nelayan atau pelaku utamanya menggunakan Kapal Penangkapan ikan dengan mesin Kapal Motor/Diesel (KM) bertenaga $<7 \mathrm{PK}$ - $24 \mathrm{PK}$, tergantung dari daya jelajah nelayan tersebut. Jumlah total armada dan alat tangkap di Kecamatan Cantigi berjumlah 2.743 unit dengan total nelayan berjumlah 2.272 orang.

Alat tangkap Sero merupakan jenis alat tangkap ramah lingkungan yang banyak digunakan oleh nelayan di Cantigi, dengan total alat tangkap sero yaitu berjumlah 1.010 unit (Tabel 2), selain itu terdapat pula bagan 630 unit, alat tangkap udang 439 unit, dan alat tangkap lainnya seperti arad, rampus, milenium, dan lain-lain. Selain jenis alat tangkap yang sudah diuraikan pada Tabel 2, masih ditemukan alat tangkap yang destruktif (berdasarkan PERMENKP No.02 Tahun 2015 mengenai larangan penggunaan alat penangkapan Pukat Hela (Trawls) dan Pukat Tarik (Seine nets)) yang digunakan 
Tabel 3. Keragaan Kelompok Perikanan di Kecamatan Cantigi

\begin{tabular}{|c|c|c|c|c|c|c|c|}
\hline \multirow[b]{2}{*}{ Desa } & \multicolumn{3}{|c|}{ Usaha Perikanan } & \multirow{2}{*}{$\begin{array}{c}\text { Jumlah } \\
\text { Total }\end{array}$} & \multicolumn{3}{|c|}{ Kelas Kelompok } \\
\hline & KUB & $\begin{array}{l}\text { POKDA- } \\
\text { KAN }\end{array}$ & $\begin{array}{l}\text { POKLA- } \\
\text { SAR }\end{array}$ & & Pemula & Madya & Utama \\
\hline Cangkring & 7 & 13 & 2 & 22 & 21 & & 1 \\
\hline Cantigi Kulon & 18 & 7 & 3 & 28 & 26 & 2 & \\
\hline Cantigi Wetan & 1 & 2 & & 3 & 3 & & \\
\hline Lamaran Tarung & 3 & 17 & 2 & 22 & 22 & & \\
\hline $\begin{array}{l}\text { Panyingkiran } \\
\text { Kidul }\end{array}$ & & 4 & & 4 & 4 & & \\
\hline Panyingkiran Lor & 1 & 3 & 2 & 6 & 6 & & \\
\hline Cemara & 2 & 8 & 1 & 11 & 10 & 1 & \\
\hline JUMLAH & 32 & 54 & 10 & 96 & 92 & 3 & 1 \\
\hline
\end{tabular}

Sumber : Data Hasil Olahan, 2018

masyarakat yaitu pukat. Penggunaan alat tangkap tersebut dapat mengakibatkan penurunan sumberdaya ikan yang mengancap kelestarian sumberdaya hayati perikanan. Oleh karena itu terdapat batasan penggunaan alat tangkap dengan tujuan untuk menganti alat tankap yang lebih ramah lingkungan.

Produksi pengolahan yang ada di Kecamatan Cantigi sudah terbilang cukup maju, walaupun dalam proses pengeringannya masih menggunakan proses yang tradisional yaitu tergantung pada sinar matahari,cuaca, adapun jumlah RTP Pengolahan yaitu sebesar 95 RTP.

\section{Keragaan Kelompok Perikanan di Kecamatan Cantigi}

Kecamatan Cantigi memiliki kelompok perikanan yang cukup baik bedasarkan sektor usahanya meliputi budidaya, penangkapan dan pengolahan. Kelompok tersebut mengalami banyak perubahan dalam jumlah di setiap tahunnya, adapun bentuk penumbuhan kelompok didasari oleh adanya proses pemberdayaan untuk meningkatkan minat pelaku utama dalam berkelompok, namun ada juga didasari kebutuhan akan bantuan dana yang bersyaratkan harus berkelompok. Berikut gambaran umum kelompok perikanan yang ada di Kecamatan Cantigi (Tabel 3).

Tabel 3, menyatakan bahwa jumlah kelompok yang tertinggi yang ada di Kecamatan Cantigi yaitu pada kelompok budidaya perikanan dengan total 54 kelompok, KUB sejumlah 32 kelompok dan poklasar sebesar 10 kelompok, sejalan dengan tingginya jumlah RTP budidaya, kelompok budidaya tersebar merata di masing- 
masing desa yang ada di Kecamatan Cantigi. Dengan tingginya jumlah kelompok yang ada di Kecamatan Cantigi, seharusnya usaha dalam setiap bidang dapat berjalan lebih baik. Bedasarkan hasil survei dan observasi menyimpulkan bahwa kondisi kelompok KUB, POKDAKAN dan POKLASAR di Kecamatan Cantigi masih banyak terdapat kelompok kelas pemula, (Tabel 3) jumlah kelompok dengan jenjang kelas pemula berjumlah 92 dan madya 3 , utama 1 kelompok. Hal ini bisa terjadi karena kurangnya pendampingan dan sosialisasi tentang kelompok, serta tujuan dan fungsi kelompok di dirikan memiliki tujuan yang rata-rata hanya meminta bantuan

\section{Karakteristik Sosial dan Ekonomi Responden}

Pengembangan subsektor perikanan sangat dipengaruhi oleh beberapa aspek penting baik sosial dan ekonomi. Aspek - aspek tersebut terdiri dari aspek pembiayaan/permodalan, pasar/konsumen, sarana dan prasarana, sumberdaya manusia (SDM) itu sendiri. Aspek-aspek yang akan menentukan prioritas alternatif pembangunan kegiatan subsektor perikanan yang meliputi, (1) perikanan tangkap, (2) perikanan budidaya, (3) pengolahan hasil perikanan (Syarief, Rustiadi, dan Hidayat 2014).
Karakteristik sosial dan ekonomi yang dapat berpengaruh terhadap pendapatan pelaku utama diantaranya seperti usia, lama usaha, pendidikan, produksi, penghasilan yang diperoleh dari melakukan usaha dan penghasilan lainnya. Hal tersebut tentunya berdampak pada tingkatan pendapatan rumah tangga pelaku utama.

\section{Karakteristik Sosial Responden}

\section{Usia Responden}

Rata-rata usia responden di Kecamatan Cantigi dalam penelitian ini adalah 41,73 tahun (Tabel 4). Mayoritas responden dalam penelitian ini, 54\% berusia 41-50 tahun, selanjutnya 34\% berusia 31 - 40 tahun. Hal ini sesuai dengan Undang - Undang No. 13 tahun 2003 tentang Tenaga Kerja bahwa usia produktif adalah antara $15-63$ tahun.

Hasil penelitian menunjukkan bahwa usia responden berkisar antara $30-70$ tahun. Sebanyak $8 \%$ responden berusia di bawah atau sama dengan 30 tahun, responden yang berusia $31-40$ tahun sebanyak $36 \%$ responden berusia 41 - 50 tahun sebanyak $54 \%$, dan responden yang berusia di atas 50 tahun sebanyak $4 \%$.

\section{Pendidikan Responden}

Bedasarkan tingkat pendidikan, sebagian besar, $77 \%$ responden dalam penelitian ini merupakan tamatan 
Tabel 4. Responden bedasarkan Usia

\begin{tabular}{ccc}
\hline $\begin{array}{c}\text { Usia Responden } \\
\text { (tahun) }\end{array}$ & Jumlah & Persentase \% \\
\hline$\leq 30$ & 2 & $8 \%$ \\
$31-40$ & 9 & $34 \%$ \\
$41-50$ & 14 & $54 \%$ \\
$51-60$ & 0 & \\
$\geq 61$ & 1 & $4 \%$ \\
\hline Total & $\mathbf{2 6}$ & $\mathbf{1 0 0 \%}$ \\
\hline
\end{tabular}

Sumber : Data Hasil Olahan, 2018

Sekolah Dasar (SD), 15\% merupakan tamatan SLTP. Tingkat Pendidikan sangat mempengaruhi pelaku utama dalam menerima pengetahuan baru. Pelaku utama terkadang kesulitan untuk menerima pengetahuan-pengetahuan baru karena rendahnya pendidikan formal mereka (Rakhmanda, Suadi, dan Supardi Djasmani 2018).

Pendidikan petani pada umumnya mempengaruhi cara dan pola fikir petani dalam mengelola usaha taninya, semakin tinggi tingkat pendidikan seseorang, semakin tinggi efisien bekerja dan semakin banyak menyadari cara bertani lebih baik dan menguntungkan (Mardikanto 2009). Hasil penelitian menunjukkan bahwa pendidikan responden sangat beragam dari yang tidak tamat SD hingga tamat SLTA, dengan mayoritas berpendidikan SD; sangat sedikit responden yang menamatkan SLTP dan SLTA.

\section{Lama Usaha Responden}

Lamanya usaha yang dijalani responden sangat berkaitan dengan tingkat pengetahuan dalam usahanya dimana lama usaha responden pada penelitian ini rata-rata 17,96 tahun. Lama usaha seorang pelaku bisnis dengan menekuni bidang usahanya akan mempengaruhi produktivitasnya (kemampuan

profesionalnya/keahliannya), semakin lama menekuni bidang usahanya, akan semakin meningkat pengetahuan tentang selera ataupun perilaku konsumen (Wicaksono dan Purwanti 2010).

Pengalaman usaha di bidang perikanan pada responden berhubungan erat sampai pada tahap mencoba inovasi, sedangkan tingkat keinovatifan responden berhubungan erat sampai pada tingkat menerapkan inovasi yang dianjurkan (Hanan et al. 2013). Pernyataan tersebut berkaitan dengan hasil dari penelitian, dimana pengalaman 


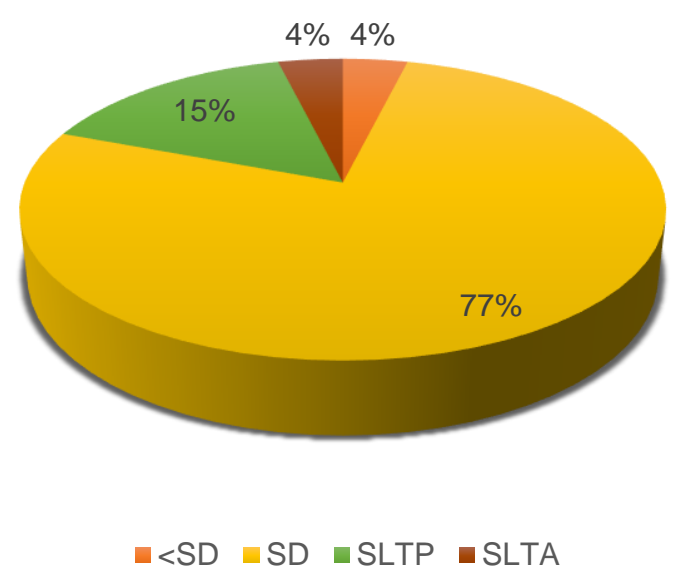

Gambar 2. Distribusi Tingkat Pendidikan Responden

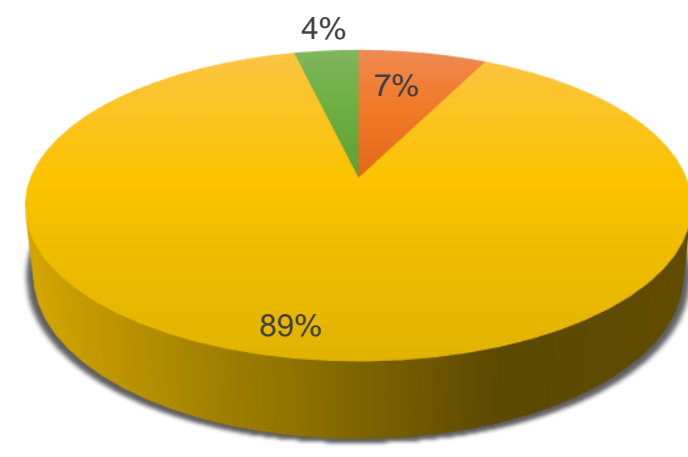

-<10 $\square 11 \mathrm{~s} / \mathrm{d} 20 \quad \square 21 \mathrm{~s} / \mathrm{d} 30$

Gambar 3. Distribusi Pengalaman Usaha

usaha responden menunjukkan bahwa pengalaman usaha responden berkisar 10 - 30 tahun, adapun responden dengan lama usaha $<10$ yaitu berkisar $7 \%$, sedangkan pada kisaran $11-20$ tahun yaitu mencapai $89 \%$, selanjutnya pada kisaran $>30$ tahun yaitu $4 \%$.

\section{Karakteristik Ekonomi Responden}

Produksi Perikanan Budidaya

Observasi dan wawancara terkait produksi budidaya perikanan yang ada di
Kecamatan Cantigi berdasarkan responden RTP budidaya, menghasilkan kesimpulan bahwa produksi rata-rata pelaku utama yaitu produksi budidaya dengan komoditas udang vanname (Litopenaeus vannamei). Komoditas udang vanname di Kecamatan Cantigi memiliki rata-rata produksi $\pm 312 \mathrm{~kg}$ dengan luas lahan rata-rata $9.375 \mathrm{~m}^{2}$ dan tingkat produktifitas rata-rata responden $0,026 \mathrm{~kg} \cdot \mathrm{m}^{-2}$, serta menggunakan teknologi yang masih tradisional. 
Tabel 5. Data Produksi Olahan Hasil Perikanan di Kecamatan Cantigi

\begin{tabular}{|l|c|c|c|c|c|c|c|c|}
\hline \multirow{2}{*}{ No } & \multirow{2}{*}{ Kecamatan } & \multicolumn{5}{|c|}{ RTP Pengolahan Tahun 2017 (Orang) } & Jumlah \\
\cline { 3 - 7 } & & Terasi & Pindang & Gesek & Masakan & Peda & Pengasapan & Total \\
\hline 1 & Cantigi & 177,30 & 164,50 & 899,20 & 98,70 & 86,30 & $\mathbf{2 5 , 6 0}$ & $1.451,60$ \\
\hline \multicolumn{2}{r|}{ Jumlah } & $\mathbf{1 7 7 , 3 0}$ & $\mathbf{1 6 4 , 5 0}$ & $\mathbf{8 9 9 , 2 0}$ & $\mathbf{9 8 , 7 0}$ & $\mathbf{8 6 , 3 0}$ & $\mathbf{2 5 , 6 0}$ & $\mathbf{1 . 4 5 1 , 6 0}$ \\
\hline
\end{tabular}

Sumber : Laporan Tahunan UTPD Kec. Cantigi Tahun 2017

\section{Produksi Perikanan Tangkap}

Berdasarkan hasil observasi dan wawancara tentang produksi perikanan tangkap terhadap responden didapat hasil bahwa produksi tidak menentu. Hal tersebut dipengaruhi oleh faktor cuaca, arus, dan pasang surut air laut. Alat tanggap jaring sero yang digunakan terdapat dua jenis, pertama jaring sero besar dengan mata jaring 3,5 inchi dan jaring sero kecil dengan mata jaring 2 inchi. Hal tersebut dipengaruhi dari daerah penangkapan ikan dimana ikan yang di tangkap oleh jaring sero kecil berjarak tidak jauh dari bibir pantai sehingga yang diperoleh memiliki peluang pendapatan hasil ikan yang berbeda, beda hal nya dengan sero besar dan jaring milenium dapat dipasang di daerah penangkapan yang jauh dari bibir pantai. Hasil yang didapat alat tangkap sero $\pm 5 \mathrm{~kg}$ ikan dengan rata-rata komoditas tangkapan yang bervariasi, diantaranya (ikan petek, cumi, udang, kembung, layur, dll).
Produksi Pengolahan Hasil Perikanan

Bedasarkan Laporan UPTD tahun (2017), produksi terbesar olahan hasil perikanan di Kecamatan Cantigi adalah olahan terasi sebesar $177,30 \mathrm{~kg}$, dan ikan gesek/ikan asin sebesar 899,20 kg. Hal tersebut sesuai dengan hasil observasi dan wawancara, di mana ratarata pengolahan yang ada di Kecamatan Cantigi memiliki usaha olahan terasi dan ikan asin, dengan produksi responden rata-rata sebesar $206 \mathrm{~kg}$ dengan lama produksi \pm 1 minggu.

Produksi olahan perikanan di Kecamatan Cantigi memiliki jumlah total $1.451,60$ ton yang terdiri dari olahan terasi, pindang, gesek, masakan,dll. Berikut rincian hasil produksi masingmasing produk olahan (Tabel 5)

\section{Analisis Usaha Perikanan Budidaya}

Pemasaran ikan hasil budidaya di Kecamatan Cantigi terdiri dari komoditas rumput laut, bandeng dan udang Vannamei. Pembudidaya di Kecamatan Cantigi memiliki pola pemasaran tidak langsung. Adapun ukuran hasil panen pada budidaya udang vannamei yaitu 70 ekor.kg-1 dengan harga jual ke pengepul 
yaitu Rp. $65.000 \mathrm{~kg}^{-1}$. Komoditas bandeng memiliki harga jual di pengepul yaitu Rp. $12.500 \mathrm{~kg}^{-1}$ dengan jumlah ikan 3 ekor. $\mathrm{kg}^{-1}$. Adapun untuk komoditas rumput laut (Gracilaria) biasanya pembudidaya menjual ke pengepul dengan kondisi kering dengan harga jual Rp. $3.500 \mathrm{~kg}^{-1}$.

\section{Berdasarkan analisis usaha} pembesaran udang vanname responden mendapat keuntungan Rp. 5.526.666 siklus $^{-1}$, dan akan mengalami titik impas atau BEP (Break Event Point) jika dapat memproduksi sebanyak 18,62 kg Ikan, usaha ini berada pada titik impas $\mathrm{R} / \mathrm{C}$ Ratio sebesar 2,2 yang mana usaha ini sudah cukup layak untuk dilajutkan karena usaha tersebut memiliki titik impas lebih dari $1(>1)$. Hal tersebut sesuai dengan hasil penelitian Chusnul, Januar, dan Soejono (2010). Pengaruh tingginya R/C Ratio pada budidaya udang vanname disebabkan produksi yang besar, diimbangi kualitas udang yang baik dengan harga jual yang baik pula.

\section{Analisis Usaha Perikanan Tangkap}

Menurut Harifuddin, Budiman, dan Aisyah (2011) bahwa produksi yang tinggi dapat mendorong terlaksananya kegiatan pemasaran yang melibatkan beberapa lembaga pemasaran. Pemasaran hasil tangkapan nelayan kecamatan Cantigi sebagian besar dijual ke pengepul dengan pola pemasaran tidak langsung. Penetapkan harga pada setiap jenis ikan hasil tangkapan dilakukan oleh pengepul. Dari perhitungan analisis usaha, bahwa kegiatan usaha penangkapan ikan mengalami titik impas atau BEP (Break Event Point) setelah memproduksi sebanyak $162 \mathrm{~kg}$ ikan dengan keuntungan yang didapat yaitu sebesar Rp. 4.131 .700 bulan $^{-1}$.

\section{Analisis Usaha Pengolahan Hasil Perikanan}

Pemasaran pada kegiatan pengolahan hasil perikanan dengan usaha terasi ikan melakukan pemasaran secara semi langsung. Hal tersebut dikarenakan terasi ikan dari produsen dibeli oleh pengepul kemudian dijual lagi oleh pengepul ke komsumen akhir. Berdasarkan perhitungan analisis usaha, bahwa usaha yang dijalankan memiliki BEP (Break Event Point) sebesar Rp. 720.449 rupiah dan $48,42 \mathrm{~kg}$. BEP merupakan saat dimana penghasilan total (total revenue) sama dengan pembiayaan total (total cost) (Simanungkalit 2008). Jadi apabila pembiayaan total melebihi pendapatan total, suatu usaha akan mengalami kerugian. Dalam hal ini keuntungan yang didapat yaitu sebesar Rp. 1.605.071 dengan $R / C$ ratio sebesar 1,69 , sehingga menunjukan bahwa usaha tersebut layak untuk dijalankan karena $R / C$ ratio $>1$ dan 
Tabel 6. Masalah Teknis Produksi Perikanan di Kecamatan Cantigi

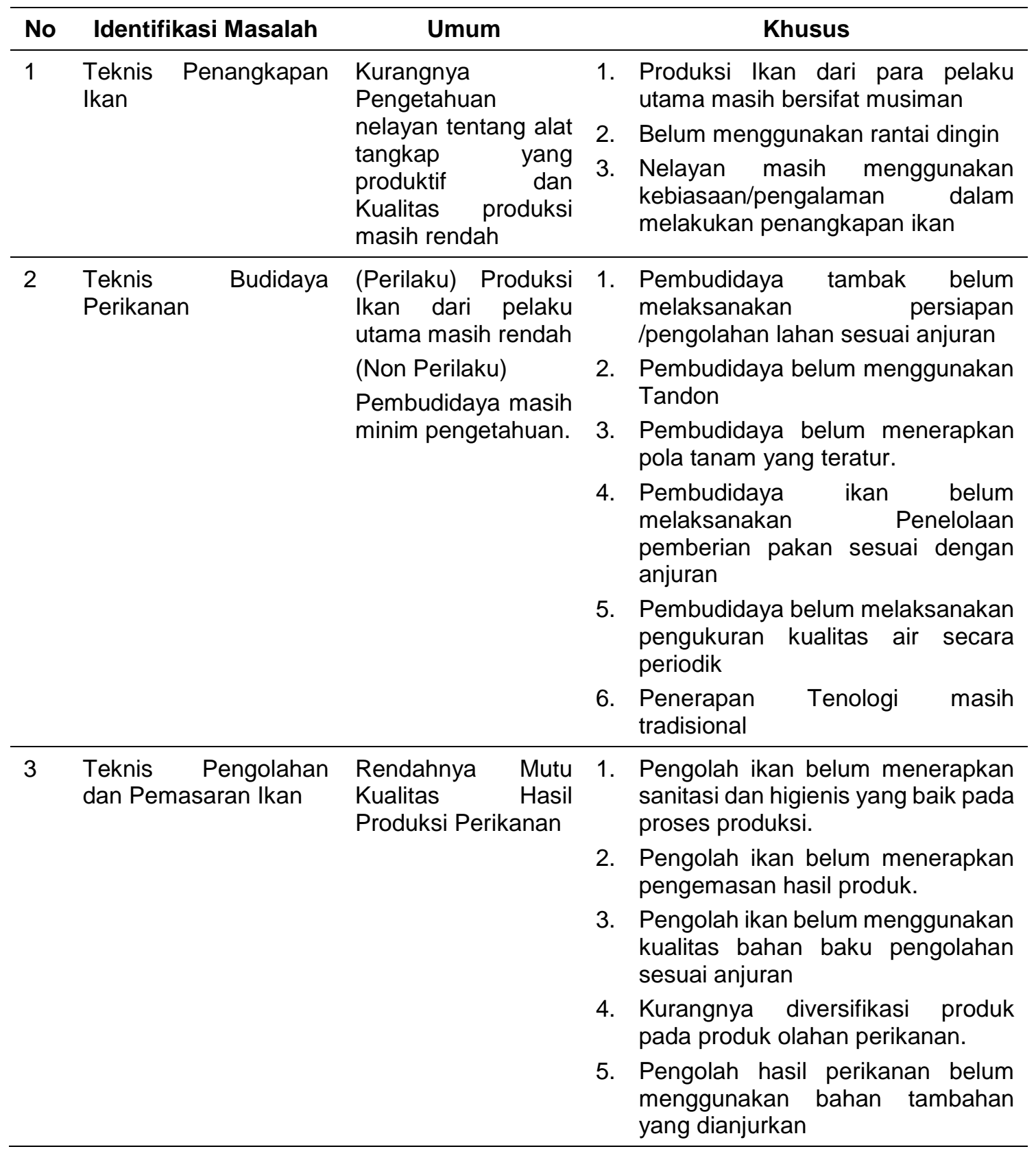

Sumber : Data Hasil Olahan, 2018

mampu menghasilkan keuntungan

sebanyak 1,69 kali dari biaya

produksinya dan melebihi biaya total.

\section{Analisis Permasalahan}

Analisis Permasalahan yang digunakan yaitu menggunakan Fault Tree Analysis yang disusun bedasarkan hasil observasi dan wawancara yang dilaksanakan selama penelitian. 
Terdapat beberapa masalah yang masih menjadi kendala dalam produksi perikanan di Kecamatan Cantigi yakni kesenjangan antara data potensial dengan data aktual. Terdapat beberapa masalah yang meliputi masalah umum teknis (Tabel 6), sosial (Tabel 7), dan masalah ekonomi (Tabel 8) yang meliputi produksi perikanan tangkap, budidaya, dan pengolahan pemasaran di kecamatan cantigi.

\section{Analisis Permasalahan Aspek Teknis}

Berdasarkan Tabel 6 terdapat permasalahan dari aspek teknis yang terdapat dari masing-masing produksi perikanan, dan terdapat kesenjangan di mana teknis budidaya udang vannamei tidak sesuai dengan SNI 8037.1: 2014. Budidaya udang vanname di Kecamatan Cantigi masih menggunakan cara tradisional, menggunakan pakan alami secara berlebihan dan tidak sesuai dengan pengelolaan pakan sesuai anjuran SNI. Bibit atau benih yang digunakan bukan benih yang berkualitas, tidak sesuai dengan SNI 01-7252-2006 tentang benih udang vannamei (Litopenaeus vannamei). Dari hasil observasi dan data SNI yang digunakan dapat disimpulkan bahwa permasalahan tersebut sangat kritis dan rata-rata pembudidaya di kecamatan Cantigi memiliki karakteristik yang sama.
Permasalahan yang terjadi dalam pengolahan perikanan di Kecamatan Cantigi yaitu rendahnya kualitas olahan. Hal tersebut disebabkan pengendalian mutu hasil dan keamanan produk masih. Dalam melakukan pengolehan ikan santitasi dan higiene yang dilakukan masih sangat kurang, bahan baku yang digunakan sudah terkontaminasi oleh udara dan binatang lainnya yang dapat menyebabkan pembusukan. Alat dan bahan baku yang digunakan tidak sesuai dengan Keputusan Menteri Kelautan Dan Perikanan Nomor 52A Tahun 2013 tentang Persyaratan Jaminan Mutu dan Keamanan Hasil Perikanan pada Proses Produksi, Pengolahan dan Distribusi.

\section{Analisis Permasalahan Aspek Sosial}

Dalam aspek sosial, kelompok yang terdapat di Kecamatan Cantigi memiliki karakteristik dan tujuan sebagai kelompok aspirasi, yaitu kelompok yang hanya didirikan untuk mendapatkan program-program aspirasi dan dana bantuan serta pinjaman dari pemerintah. Hal tersebut terlihat dari jumlah kelompok yang banyak namun ketika dilakukan observasi ternyata kelompok tersebut sudah tidak aktif. Hal ini disebabkan karena kurangnya kesadaran, pengetahuan dan informasi dalam berkelompok.

Dari permasalahan tersebut perlu adanya upaya pemerintah untuk 
Tabel 7. Masalah Sosial Produksi Perikanan di Kecamatan Cantigi

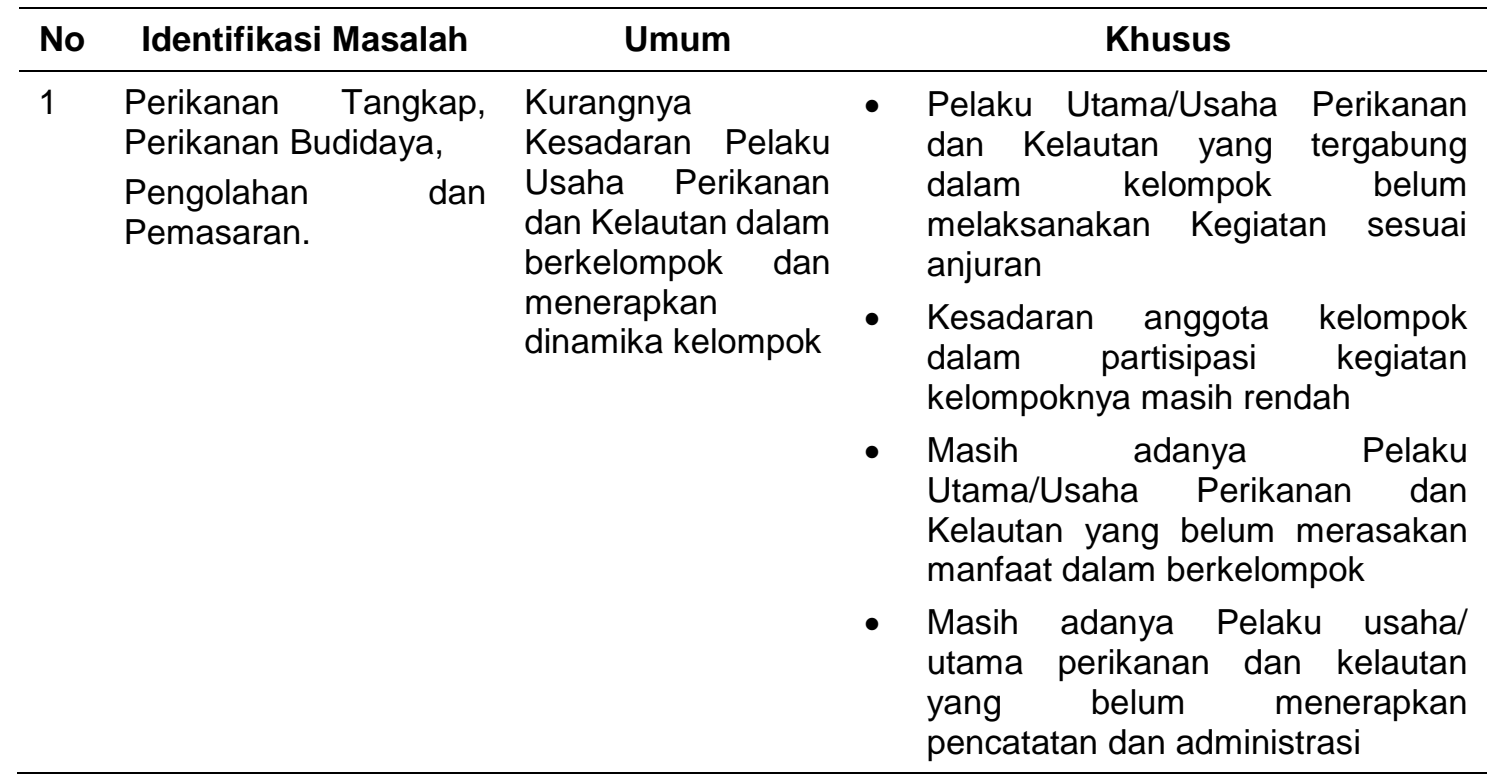

Sumber : Data Hasil Olahan, 2018

Tabel 8. Masalah Ekonomi Produksi Perikanan di Kecamatan Cantigi

\begin{tabular}{|c|c|c|c|c|}
\hline No & Identifikasi Masalah & & um & Khusus \\
\hline \multirow[t]{3}{*}{1} & $\begin{array}{l}\text { Perikanan Tangkap, } \\
\text { Perikanan Budidaya, }\end{array}$ & $\begin{array}{l}\text { Biaya } \\
\text { Tinggi }\end{array}$ & Produksi & $\begin{array}{l}\text { - Manajerial Usaha masih belum } \\
\text { tersistematis }\end{array}$ \\
\hline & $\begin{array}{l}\text { Pengolahan } \\
\text { Pemasaran. }\end{array}$ & & & $\begin{array}{l}\text { - } \quad \text { harga bahan produksi yang tinggi } \\
\text { - } \quad \text { Rendahnya tingkat kemitraan yang } \\
\text { terjalinnya dengan pihak ketiga } \\
\text { sehingga dalam penentuan harga } \\
\text { masih didominasi oleh pembeli } \\
\text { (Bargaining Position) }\end{array}$ \\
\hline & & & & $\begin{array}{l}\text { - Rendahnya akses permodalan } \\
\text { dengan lembaga keuangan }\end{array}$ \\
\hline
\end{tabular}

Sumber : Data Hasil Olahan, 2018

melakukan pembinaan dan penekanan terhadap persyaratan pembentukan kelompok yang sesuai dengan aturan hukum yang ada.

\section{Analisis Permasalahan Aspek Ekonomi}

Masalah ekonomi yang di hadapi di Kecamatan Cantigi merata di setiap sektor usaha. Masalah tersebut dirasakan oleh $80-95 \%$ pelaku utama perikanan sehingga penting untuk segera diselesaikan. Masalah tersebut adalah harga pakan yang tinggi yang menyebabkan pembudidaya tidak optimal dalam pemberian pakan.

Permasalahan yang menjadi prioritas (Tabel 8) yaitu rendahnya akses permodalan. Hal ini disebabkan oleh kurangnya pengetahuan pelaku utama 
tentang akses permodalan dan kurangnya sosialisasi kepada lembaga penunjang yang lain yang terkait permodalan. Keterkaitan lembaga penunjang dan permodalan tentu perlu di lakukan dan pendampingan serta penyuluhan tentang lembaga permodalan perlu di sampaikan. Menurut Hidayat (2013), peningkatan kapasitas individu juga dapat dilakukan dalam bentuk peningkatan keterampilan, teknologi, jaringan pemasaran dan fasilitasi manajemen keuangan.

\section{Uji Prioritas Masalah}

Hasil dari analisis permasalahan teknis, sosial dan ekonomi selanjutnya di uji prioritas. Tujuan dari uji prioritas sendiri bertujuan untuk menentukan permasalahan mana yang harus segera diselesaikan. Penentuan skala prioritas masalah menggunakan skoring pada Gawat, Mendesak dan Penyebaran (GMP), akar masalah ditentukan dari hasil kuesioner dan wawancara terhadap responden. Responden melakukan penilaian dengan skoring dari analisis GMP.

Dari hasil analisis prioritas masalah GMP disimpukan bahwa masalah yang menjadi pokok utama di bidang teknis : a) nelayan yang masih belum menerapkan rantai dingin, b) pembudidaya belum melaksanakan pengelolaan pakan yang sesuai dan c) pengolah yang belum menerapkan sanitasi higiens pada proses produksi. Masalah utama pada aspek sosial adalah kesadaran anggota kelompok dalam partisipasi kegiatan kelompoknya masih rendah. Permasalahan utama pada aspek ekonomi adalah harga bahan produksi yang tinggi.

\section{SIMPULAN DAN SARAN}

\section{Simpulan}

1. Kecamatan Cantigi memiliki potensi perikanan yang cukup besar dengan luas $116,84 \mathrm{~km}^{2}$ dengan 7 desa adminitratif. Sumberdaya manusia di Kecamatan Cantigi berjumlah 27.811 jiwa, dengan jumlah penduduk laki-laki 13.824 dan perempuan 13.987 jiwa. Bedasarkan jenjang usia produktif Kecamatan Cantigi memiliki 19.366 jiwa atau $70 \%$ dari total jumlah penduduk yang berada pada usia produktif dengan umur 15-64 tahun.

2. Kecamatan Cantigi memiliki total rumah tangga perikanan sebesar 6.177 RTP, yang terdiri dari pelaku utama pembudidaya yang berjumlah 3.810 RTP, perikanan tangkap berjumlah 2.272 RTP, dan Pengolahan 95 RTP. Tingginya jumlah RTP serta potensi wilayah yang ada, Kecamatn Cantigi cocok untuk melakukan usaha perikanan. 
3. Permasalahan yang terdapat di Kecamatan Cantigi yang umum terjadi di masyarakat yaitu pada bidang teknis : a) nelayan yang masih belum menerapkan rantai dingin, b) pembudidaya belum melaksanakan pengelolaan pakan yang sesuai dan c) pengolah yang belum menerapkan sanitasi higiens pada proses produksi. Masalah utama pada aspek sosial adalah kesadaran anggota kelompok dalam partisipasi kegiatan kelompoknya masih rendah. Permasalahan utama pada aspek ekonomi adalah harga bahan produksi yang tinggi.

\section{Saran}

Permasalahan yang ada di Kecamatan Cantigi tentu perlu di selesaikan, perlunya pendampingan dan penyuluhan yang lebih intens sehingga produksi perikanan yang ada di Kecamatan Cantigi menjadi lebih baik.

\section{DAFTAR PUSTAKA}

Ambari, M. 2017. "Kapal Berukuran Kecil Lakukan Praktik Perikanan Ilegal?" Mongabay. Diambil 3 April 2019 (https://www.mongabay.co.id/2017 /12/12/kapal-berukuran-kecillakukan-praktik-perikanan-ilegal/). Anthony, Roberto dan Sunday Noya. 2015. "The Application of Hazard Identification and Risk Analysis
(HIRA) and Fault Tree Analysis (FTA) Methods for Controling Occupational Accidents in Mixing Division Dewa-Dewi Farm." Jurnal IImiah Teknik Industri 3(2).

BPS. 2012. Kabupaten Indramayu dalam Angka 2012. Indramayu (ID): Badan Pusat Statistik Kabupaten Indramayu.

BPS. 2015. Kabupaten Indramayu dalam Angka 2015. Indramayu (ID): Badan Pusat Statistik Kabupaten Indramayu.

BPS. 2017. Provinsi Jawa Barat dalam Angka 2017. Bandung (ID): Badan Pusat Statistik Provinsi Jawa Barat. BPS. 2018. Kecamatan Cantigi dalam Angka 2018. Indramayu (ID): Badan Pusat Statistik Kecamatan Cantigi.

Chusnul, Dwi Zanuarita, Jani Januar, dan Djoko Soejono. 2010. "Kajian Sosial Ekonomi Usaha Budidaya Udang Vannamei (Litopenaeus vannamei) di Desa Dinoyo Kecamatan Deket Kabupaten Lamongan." JSEP (Journal of Social and Agricultural Economics) $4(1): 15-23$.

Hanan, Abdul, Walson H. Sinaga, Nayu Nurmalia, dan Ani Leilani. 2013. "Analisis Tingkat Adopsi Inovasi Teknologi Budidaya Ikan Lele Sangkuriang pada Kelompok 
Ranca Kembang di Kecamatan Cipanas Kabupaten Lebak." Jurnal Penyuluhan Perikanan dan Kelautan 7(1):1-15.

Harifuddin, Budiman, dan Aisyah. 2011.

"Analisis Margin dan Efisiensi

Pemasaran Rumput Laut di Desa

Mandalle Kecamatan Mandalle, Kabupaten Pangkep." Agribisnis 10(3):38-48.

Hidayat. 2013. "Peningkatan Kapasitas Kelembagaan Nelayan." Citra Lekha 17(1).

Mardikanto, Totok. 2009. Sistem penyuluhan pertanian. Surakarta (ID): UNS Press.

Rakhmanda, Andhika, Suadi, dan Supardjo Supardi Djasmani. 2018. "Role of Fisher Group in The Fisheries Development in Sadeng Coast Gunungkidul Regency." Sodality: Jurnal Sosiologi Pedesaan 6(2).

Sevilla, Consuelo G., Jesus A. Ochave, Twila G. Punsalan, Bella P. Regala, dan Gabriel G. Utiarte. 1992. Research methods. Rex Bookstore, Inc.

Simanungkalit, Rutkaya. 2008. "Inventaris Makanan Khas Toba dan Strategis Pengembangan Tipa-Tipa di Toba Samosir." Universitas Sumater Utara.
Sunyoto, Danang. 2011. Statistik deskriptif untuk Ekonomi. Bandung (ID): Yrama Widya.

Syarief, Ade, Eman Rustiadi, dan Aceng Hidayat. 2014. "Analisis Sub Sektor Perikanan dalam Pengembangan Wilayah Kabupaten Indramayu." TATALOKA 16(2):84-93.

Wicaksono, Rezal dan Evi Yulia Purwanti. 2010. "Analisis Pengaruh PDB Sektor Industri, Upah Riil, Suku Bunga Riil, dan Jumlah Unit Usaha Terhadap Penyerapan Tenaga Kerja pada Industri Pengolahan Sedang dan Besar di Indonesia Tahun 1990-2008 [Skripsi]." Universitas Diponegoro. 